\title{
Sportstegninger i Politiken
}

\author{
af Per Jørgensen
}

I over fyrre år, fra århundredskiftet til 2. verdenskrig, blev Politikens artikler om sport ledsaget af tegninger. De udgør et righoldigt kildemateriale for alle, der ønsker at beskæftige sig med sportsjournalistikkens historie eller som, hvad der er tilfældet $i$ denne årbog, ønsker at gøre brug af et overset, men smukt illustrationsmateriale.

I denne årbog er det en til hudløshed gentagen pointe, at idrætshistorien fører en stedmoderlig tilværelse sammenlignet med den ,rigtige" historie. Det er selvfølgelig så sandt, som det er skrevet, og dette forhold vil forblive uændret lige så længe idrætten betragtes løsrevet fra det øvrige samfund eller som noget mindre væsentligt.

Den 1. oktober 1984 fyldte vort største dagblad, Politiken 100 år. Jubilæet blev fejret efter alle kunstens regler, bl.a. blev der udgivet en glimrende jubilæumsbog, en scrapbog, samlet og redigeret af Bo Bramsen.

Symptomatisk er det imidlertid, at ud af de to binds over 1000 sider er sporten blevet tildelt i omegnen af $1 \%$. Dette til trods for at Politiken næsten fra start var det dagblad, der gjorde mest ud af at behandle sporten journalistisk, og som i høj grad siden har dannet skole på sportsjournalistikkens område. Og til trods for at Politikens sport har haft en stadig stigende andel af den tilrådighedstående plads i den daglige avis, hvor den formodentlig har og har haft en særdeles stor læserskare.

Også efter Politikens jubilæumsbog er sportsjournalistik altså et næsten jomfrueligt område $i$ en historisk sammenhæng. Egentlig lidt paradoksalt når man tænker på, at sport nu i snart 100 år har beskæftiget en stadig større og større del af flere og flere menneskers hverdag, har fået mere og mere plads $i$ medierne, og at kildematerialet er stort og lettilgængeligt. Kun inden for danskstudiet ved vore universiteter har man beskæftiget sig seriøst med sportsjournalistik. Som regel i forbindelse med ideologikritiske eller tekstanalytiske specialer og aldrig med en egentlig historisk indfaldsvinkel.

Formålet med denne artikel er $\mathrm{i}$ øvrigt slet ikke at beskæftige sig med den skrevne sportsjournalistik, men at gøre opmærksom på, at der i en stor del af dette århundrede har været en tradition for at anvende tegninger som illustration til sportsjournalistiske artikler. Det var naturligvis selvfølgeligt $i$ 
århundredets første år, hvor man slet ikke kunne bringe aktuelle fotografier $\mathrm{i}$ avisen, men det var en tradition, der fortsatte helt op mod 2. verdenskrig, hvor fotografiet for længst havde fundet sin plads i dagens avis. I denne periode fortsætter tegningen med at være den personlige kommentar til den sportslige begivenhed ved siden af selve artiklen og det redaktionelt udvalgte fotografi.

I Politiken dukker de første tegninger op i 1898 med tegneren Rasmus Christiansens ansættelse. Efter sigende var både Hørup og Brandes modstandere af illustrationer, som indtil da udelukkende var forbeholdt annoncerne. Sportsstoffet bliver ret hurtigt derefter forsynet med tegninger. Hvor mange sportstegninger Politiken bragte de næste ca. 40 år, er det naturligvis umuligt at udtale sig nøjagtigt om, men det drejer sig formentlig om flere tusinde. De følgende eksempler er alle hentet fra perioderne august-oktober 1900-1940. Der er således ikke eksempler fra vinteridræt. Det vil føre for vidt her at komme ind på hvem, der står bag de mange tegninger. Dels er de ofte anonyme, dels ser det ud til, at de fleste af Politikens mange tegnere har været involveret. Ingen nævnt, ingen glemt.

M.h.t. forholdet mellem tegningens indhold og artiklens indhold, må det siges, at der sædvanligvis var god overensstemmelse. Det er sjældent, tegningen ikke beskriver situationer, der er beskrevet $\mathrm{i}$ artiklen (og omvendt). Dette er især tilfældet før første verdenskrig, men man kan dog finde undtagelser i hele perioden.

Som nævnt blev sportsstoffet regelmæssigt illustreret fra århundredskiftet, og eksemplet side 139, der stammer fra den 14. juli 1900 er typisk for perioden. Tegningen er fra "Grand prix-Løbene“ "på Ordrupbanen dagen før, og tegneren har valgt at illustrere artiklen med en blanding af persontegning og karakteristiske og handlingsmættede, dramatiske situationer, som det $i$ datiden endnu ikke var muligt at gengive fotografisk.

Pressefotografiet dukker i øvrigt først op december 1908, hvor Politiken ansætter Danmarks første pressefotograf, Holger Damgaard. Men det var efter, at Henrik Cavling i 1905 havde overtaget ledelsen i Politiken efter Edvard Brandes, og ny teknik var indført. Cavling var en stor tilhænger af den illustrerede avis.

Perioden fra 1905 frem mod 1. verdenskrig må betegnes som noget af en gylden periode for bladtegningen i Politiken. Det kan man overtyde sig om ved selvsyn, idet såvel forsiden som de fleste af de bladtegninger, der er spredt rundt om i denne årbog, er fra denne periode.

Tegningerne er ofte $\mathrm{i}$ stort format. De er talrige, detaljerede og ofte særdeles smukke. I periodens begyndelse er tegningerne enerådende som illustration i avisen. Her eksperimenteres ofte med sportstegningens muligheder som på forsidebilledet fra 21.8.1905, hvor Ellegaard er ,fanget“ i 


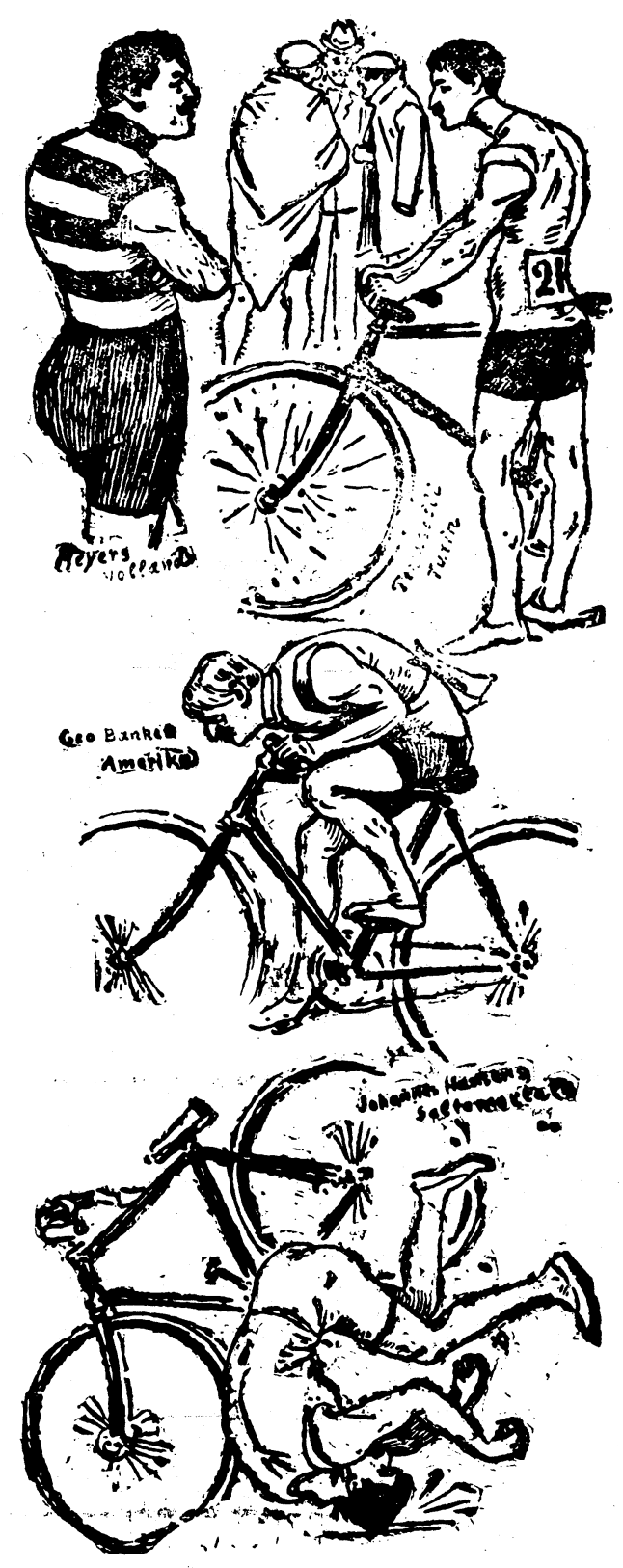


opløbet på gårdsdagens grand-prix.

Tegneren forsøger her at skildre den kolossale fart, Torvald Ellegaard havde på, da han for øjnene af over 6000 tilskuere vandt finalen i sprint foran Poulain.

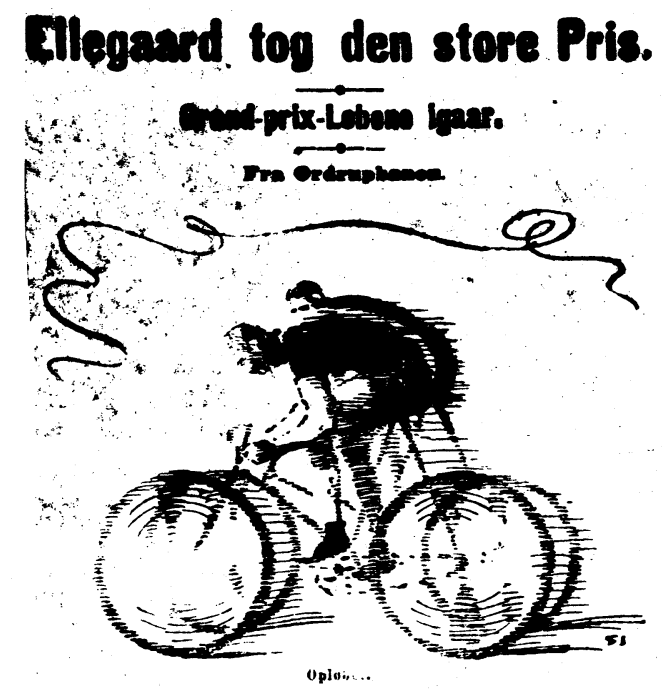

Siden hen i denne ,,gyldne“ periode bærer tegningerne meget præg af det konkurrenceforhold, der opstod til fotografiet, der som nævnt blev indført $i$ slutningen af 1908. Det var en ulige kamp, der blev tabt op mod 1. verdenskrig. Efter den periode måtte tegnerne omdefinere deres rolle $i$ dagens avis. Lidt hurtigt og firkantet kan man sige, at de gik fra den ,fotografisk" nøjagtige tegning til en enklere, men som tiden går også en mere personlig, kommenterende stil.

Det kan man for sportssidernes vedkommende overbevise sig om ved at betragte to af tegningerne, fra den 4. oktober 1915 fra kampen mellem de to bedste nordiske klubhold $\mathrm{i}$ fodbold, B93 og Göteborg Kamraterne. Kampen, der blev overværet af 4000 tilskuere, endte 5-1 til B93, der således fik revanche for et nederlag i Göteborg. Journalisten Edgar Aabye var i øvrigt bekymret over de høje priser. Han mente, at 1,- kr. for de billigste pladser var for meget for de mindrebemidlede. Nok ikke uden grund når man tænker på, at 1,- kr. i 1915 svarede til ca. 2 timers arbejde for en arbejdsmand. 


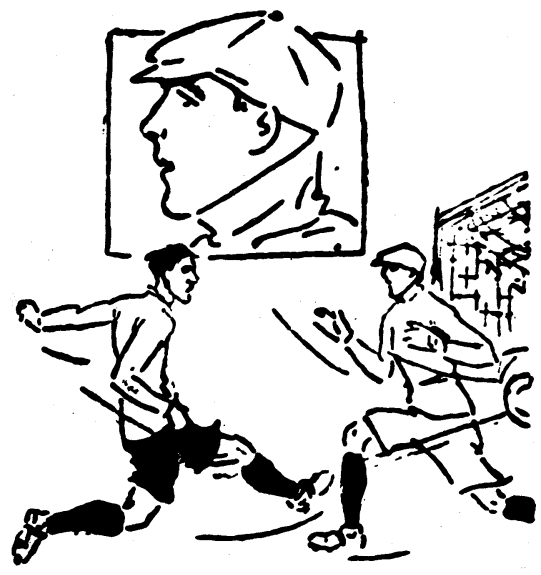

Anton Olsem mod Maclmanden.

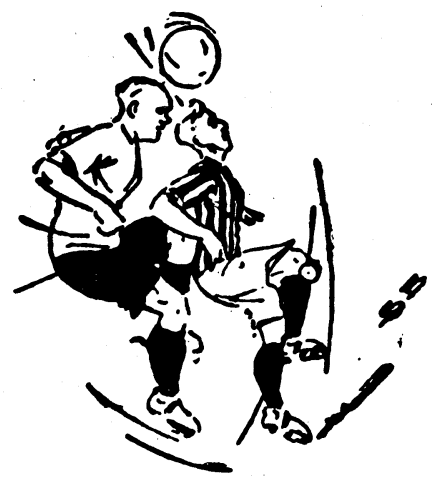

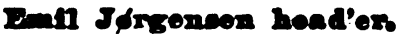

Væk er nu den store, detaljerige 3-4 spalter til fordel for små „,hurtige“ en-spaltede, handlingsmættede situationsskitser, hvor tegneren har valgt at fokusere på de tre B93 landsholdsesser, Harald Hansen, Emil Jørgensen og Anton Olsen. Tegningerne er helt typiske for denne periode.

I øvrigt må det nævnes, at på dette tidspunkt har fodbold for længst etableret sig som den største sportsgren i Danmark. Det var ikke tilfældet omkring århundredskiftet, hvor det var mere almindeligt at se tegninger fra brydning, boksning, cykelløb, roning og svømning. Ofte var der dengang i øvigt tale om fysiske aktiviteter, der egentlig ikke falder ind under betegnelsen sport, men snarere under den bredere: idræt.

Men fodbold handlede det i hvert fald om i 1920, da Danmark overraskende og forsmædeligt tabte 1-0 til Spanien ved OL i Antwerpen. Det skete som bekendt, fordi målmanden Sofus Hansen gled i det våde græs.

Det inspirerede 14 dage efter til tegningen fra kampen B 1903-Frem (3-1), den 12.9. Tegneren konstaterer, at Sofus klarer uden at glide. Det må i øvrigt retfærdigvis over for Sofus Hansen fra Frem nævnes, at uheldet i Belgien ikke var symptomatisk for ham. Han er faktisk en af Danmarks bedste målmænd gennem tiderne og opnåede da også 31 landskampe. Et meget stort antal i datiden.

Ellers er der i 1920 som i 1915 tale om små, ,hurtige“ tegninger med motiver fra begivenhedernes dramatiske højdepunkter.

I de følgende år ændres tegningernes indhold. Der er stadig tale om små tegninger af skitseagtigt tilsnit, men nu er det ikke mere de dramatiske 
situationer, der er i højsædet. Nu er det karikaturen, satiren, eller den pudsige, lidt usædvanlige situation, der er i fokus.

Den. 12.9.1925 havde ,stævnet“ udenlandsk besøg. Dennegang af en spansk klub, der blev slået 4-1. B93s Michael Rohde (Mikkel) scorede et lidt heldigt mål, hvad også fremgår af tegningen.

Det sidste mål blev scoret af Fritjof Steen, der indtil da havde gjort en uheldig figur. Men i ly af mørket lykkedes det ham at score.

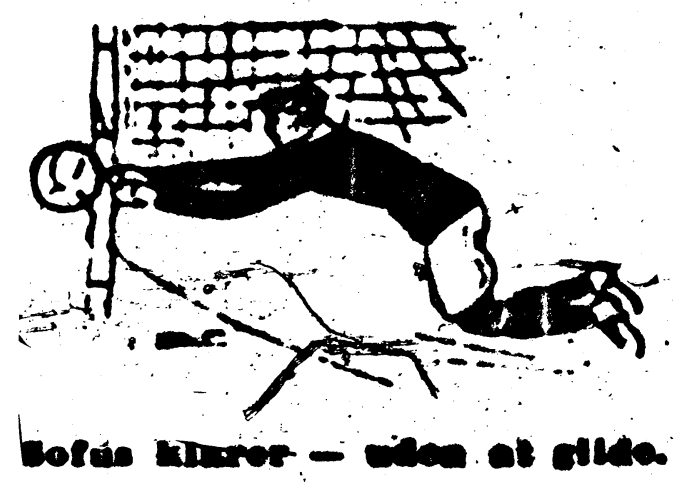

Kampen startede i øvrigt med, at danskerne kun var 8 mand på banen. Resten var endnu ikke kommet fra arbejde. De dukkede op efterhånden. Det var der ingen, der tog anstød af. Hverken journalisten eller de over 6000 tilskuere.

Fem år efter, i 1930, kan man stadig finde karikaturen og de pudsige situationer $\mathrm{i}$ tegningerne, men det ser ud som om, den dramatiske situation har fået en renaissance, og at portrættet er ved at vinde indpas.

Eksemplerne er hentet fra bokseren Kaj Axels kamp mod belgieren van Haecke den 24.10. Axel vandt. Ved samme stævne fik en af Danmarks bedste amatør-boksere gennem tiderne, Thyge Petersen, sin professionelle debut $\mathrm{i}$ letsværvægt. Han vandt også.

Portrættet var kommet for at blive, og bliver i de følgende år mere og mere dominerende. Når der i 1935 var tegninger på sportssiden, var det oftest som den 19. september, hvor Abraham Kurland igen havde vundet. Artiklen vises $i$ sin helhed side 144.

Det sidste eksempel side 145, kan således passende være fra den 2.9.1940, hvor nordmanden Erik Stai har sat nordisk rekord i højdespring med $2 \mathrm{~m}$. 

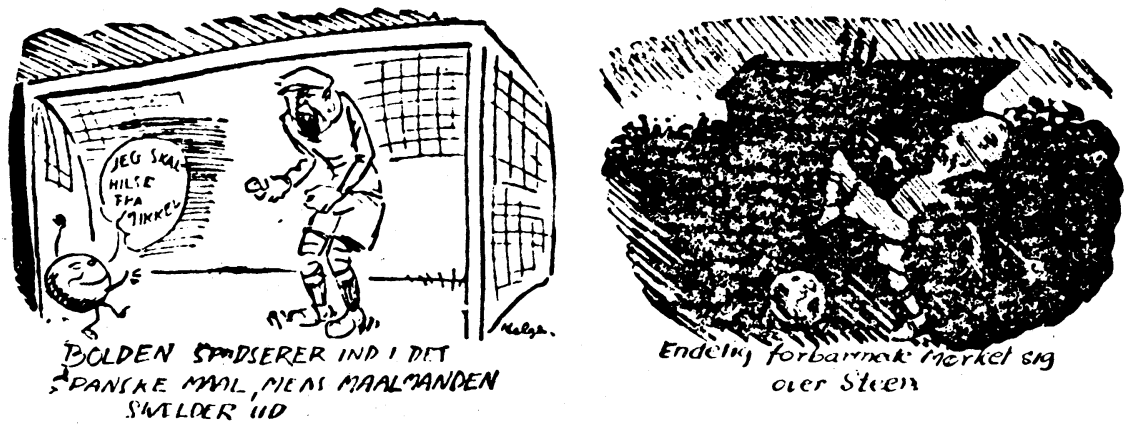

Den samtidige danske rekord havde Paul Otto med 1,91 m. Først i 1962 nåede Ole Papsøe fra Viborg de norske højder.

Hvordan passer tegningen så sammen med sportsjournalistikkens og idrættens samfundsmæssige udvikling i perioden? Det er det svært at udtale sig om. Alene af den grund, at der jo aldrig har fundet en dybtgående undersøgelse sted af, hvorledes sportsjournalistikken har udviklet sig som genre.

En grov tommelfingerregel siger, at oprindelig var referatet det almindelig-

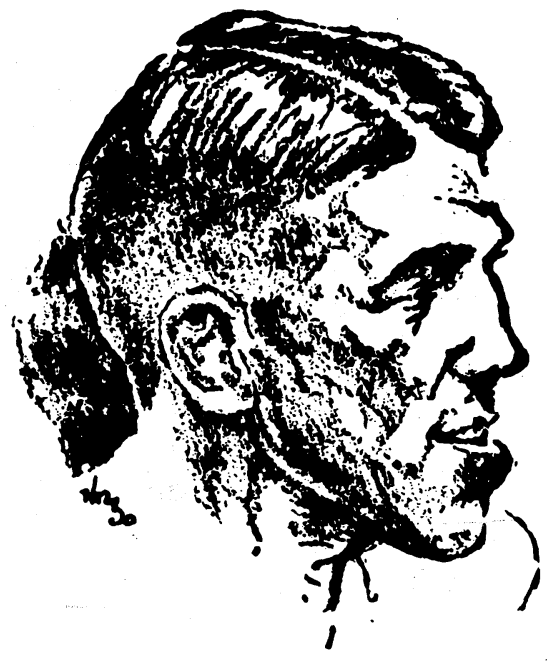

Kaj Axel.

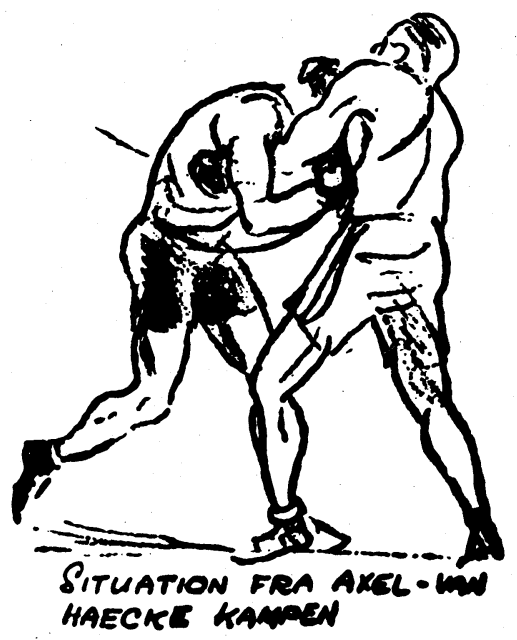




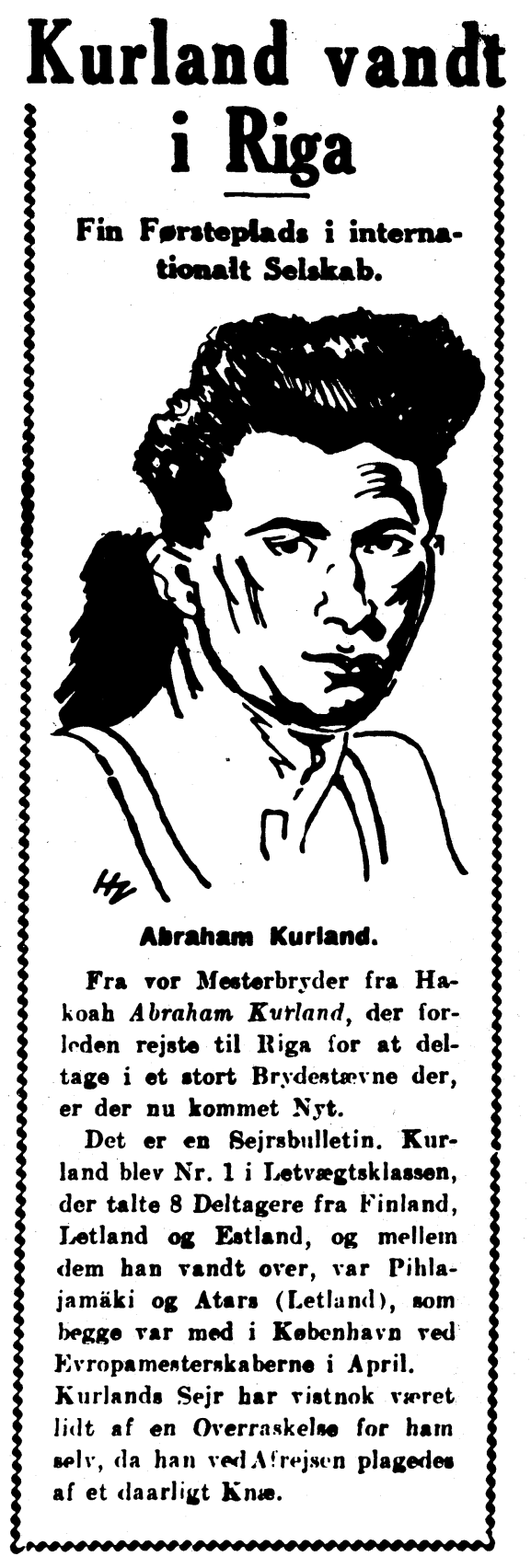




\section{Stai over 2 m i Højdespring}

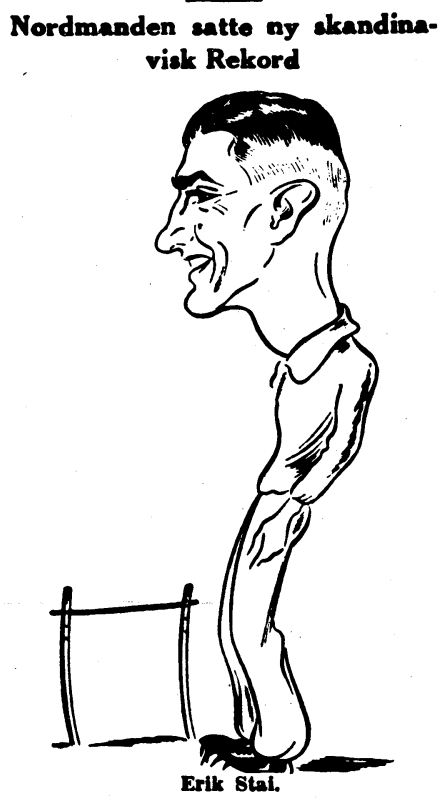

ste, mens sportsjournalistikken i vore dage ofte kendetegnes ved en hæmningsløs sammenblanding af referat, interview, reportage og kommentar.

Men den udviklingslinie forudsætter vel, at sportsjournalistikken opfattes som en nogenlunde éntydig størrelse. Og det er jo ikke tilfældet. Sportsjournalistikken i TV, Politiken, Ekstra Bladet og Information er kun svært sammenlignelig. Det har naturligvis noget at gøre med stil og holdning, men også med dead-line og målgruppe.

Hvis sammenligningen mellem sportsjournalistik og sportstegning foretages på Politiken alene, kan der måske nok anes en sammenhæng. I den første periode, hvor sportsjournalisten refererede meget, var tegningerne også ofte ,fotografisk" registrerende. Siden hen i 20 'rne og 30'rne, hvor sportsjournalisten er begyndt at besøge omklædningsrummet, hvor idrætsstoffet tilsyneladende bevidst bliver populariseret og baggrundsstoffet bliver opprioriteret, ses det også, at tegningen skifter indhold. Den forlader sin tilstræbt objektive rolle og bliver til en personlig, ofte humoristisk eller satirisk kommentar. 
Ovenstående skal dog tages med en gran salt. For sportsjournalisten var jo ikke kun refererende i gamle dage. Men man kan måske sige, at genrerne ikke blev blandet helt så meget.

Når Edgar Aabye (E.A.) f.eks. skrev en fyldig refererende artikel om grand-prix på Ordrup-banen i 1905 (21.8.), var det naturligt, at han placerede en anden artikel ved siden af under titlen „I Indrekredsen" og under pseudonymet ,,Moustache“. Her hed det bl.a.:

„,Der er ude på Cyklebanen i Ordrup en Amatørrytter, som hedder HansenChristensen. Han adskiller sig fra de andre Ryttere ved at være hjulbenet $i$ en saa ualmindelig Grad, at han - det paastaas i hvert fald - under Løbene ikke drejer Hovedet og kigger over Skuldrene for at se, om der er nogen bag ham, men bøjer Hovedet nedefter og kigger bagud gennem den af hans Ben frembragte Bue. Nu plejer der aldrig at være nogen bagved ham af den gode Grund, at han i alle Henseender er kvalificeret til at være Sidstemand ..." o.s.v., o.s.v.

I al sin strålende småperfidi, er det jo ikke meget anderledes end det „Simon“ (Magnus Thing Simonsen) kunne finde på at skrive over 60 år efter $\mathrm{i}$ den samme avis. 
Anvendt litteratur:

- ,De første 100 år"

Politikens Historie set Indefra

Politikens forlag, 1984

- Politiken

stikprøver fra august-oktober

1895-1945

Supplerende litteratur:

- Gunnar Rasmussen

Sportsjournalistik

GMT, 1974

- Sportspressen og Sportsideologi

(specialeopgave under faget dansk)

Solvejg Andersen, 1979

- Sportsjournalistikkens udvikling 1-3

Carl Ettrup

Information (30.7., 6.8., 13.8.1971)

- For Sportens Skyld

Nationalmuseet, 1972 


\title{
Det store Atletikstævne paa Stadion.
}

\begin{abstract}
Amerikanerne var overlegne I Lob, Fojdeapring og Diakon. - Men 100 Meter Lob maatte Evans opgive paa Grurd ap on Muskeleammentrokning. - Amert Larwen, der blev Nr. 2 11 mile Lobet, catte ny danak Rekord.
\end{abstract}

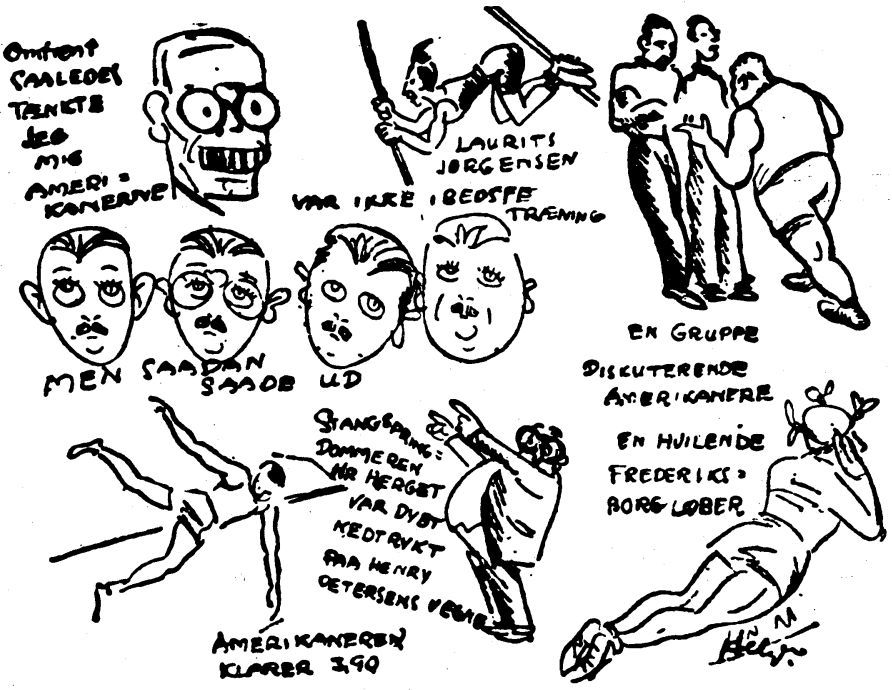

Dansk-amerikansk atletikstævne (Pol. 10.8.1925). Som det ses, er der stor forskel på sportstegningens rolle i 1925 sammenlignet med f.eks. 20 år tidligere.

Det Atletikstævne, som tegneren så personligt kommenterede fandt sted den 9. august. Amerikanerne var også dengang de danske deltagere overlegne og vandt ved et par stævner næsten alt, hvad de deltog $i$.

Et af de bedste danske resultater stod Albert Larsen, KIF, for i 1 mile-løbet. Han blev nr. 2 og satte dansk rekord. Vinderen Dodge benyttede 4 min. 20,9 sek.

Der var i 1925 endnu langt til drømmemilen. Det er der ikke $i$ dag. Tit gengæld kommer der sjældent 10.000 tilskuere. Det gjorde der engang imellem i 1925. Bl.a. ved ovennævnte stævne. 